\title{
FOSTERING OR HINDERING CREATIVITY AT WORK? MODERATING ROLE OF PROACTIVE PERSONALITY TOWARD SUPPORT AND MEANINGFULNESS
}

\author{
Handrio Adhi Pradana ${ }^{* 1}$, Zulfa Uliani*) \\ *) Department of Management, Faculty of Business and Economics, Universitas Islam Indonesia \\ Ace Partadiredja Building, Ring Road Utara, Condongcatur, Sleman, Yogyakarta 55283 Indonesia
}

\begin{abstract}
This study aims to investigate the main effects and moderating role of proactive personality on the influence of perceived organizational support and meaning of work on creativity. Data was collected from 155 professionals and knowledge workers in information technology companies with non-probability sampling using snowball technique. This study uses hierarchical regression analysis with SPSS 22 software to test hypotheses. Results revealed that perceived organizational support and meaning of work have significant positive effect on employee creativity. Moderating effect of proactive personality has successfully amplified meaning of work on creativity. An interesting and unexpected finding is that proactive personality moderate significant negative effect of perceived organizational support on creativity. That is, high level of proactivity actually weakens relationship between perceived organizational support and creativity. The finding extends creativity literature related to social exchange theory. Practical implications are also discussed in this article.
\end{abstract}

Keywords: creativity, perceived organizational support, meaning of work, proactivity

\begin{abstract}
Abstrak: Studi ini bertujuan menginvestigasi pengaruh utama dan efek pemoderasi proactive personality terhadap pengaruh dukungan organisasional persepsian dan kebermaknaan kerja pada kreativitas. Data dikumpulkan dari profesional dan pekerja pengetahuan di perusahaan teknologi informasi sebanyak 155 responden dengan sampling non-probability dan teknik snowball. Penelitian ini menggunakan analisis regresi hierarkikal dengan bantuan software SPSS 22 untuk melakukan pengujian hipotesis. Hasil mengungkapkan bahwa dukungan organisasional persepsian dan kebermaknaan kerja berpengaruh positif signifikan pada kreativitas karyawan. Efek pemoderasi proactive personality berhasil memperkuat pengaruh kebermaknaan kerja pada kreativitas. Temuan yang menariksekaligus di luar ekspektasi adalah proactive personality memoderasi negatif signifikan pengaruh dukungan organisasional persepsian pada kreativitas. Artinya, level tinggi proactivity justru memperlemah hubungan dukungan organisasional persepsian dan kreativitas. Temuan ini mengembangkan literatur kreativitas yang terkait pada teori pertukaran sosial. Implikasi praktis juga dipaparkan di artikel ini.
\end{abstract}

Kata kunci: kreativitas, dukungan organisasional persepsian, kebermaknaan kerja, proaktif

${ }^{1}$ Alamat Korespondensi:

Email: handrio.pradana@uii.ac.id 


\section{INTRODUCTION}

The external environment and increasingly fierce competition have forced many companies to continue looking for solutions in managing their resources. A company's competitive advantage is determined by the performance of its innovation. While the most powerful factor in driving innovation is the company's ability to enhance employee creativity (Mittal and Dhar, 2015). Moreover, according to Girard (2010), creativity is considered as the key to the company's long-term development and sustainability. Employee creativity is defined as the process and individual's capacity to produce ideas that are not only new, but also useful and appropriate. Creativity products include goods, services, procedures, methods or practices (Akgunduz et al. 2018).

Because creativity is an ultimate outcome variable and is one of the strong predictors of the performance of organizational innovation, studies that sought to identify the determinants of creativity have been carried out. For examples, research from Barczak et al. (2010) found antecedents of creativity in the form of group dynamics, group trust, and emotional intelligence. Other studies reveal creativity is influenced by the leader behavioral factors namely transformational and transactional leadership (Khalili, 2016). In addition, individual factors that is goal orientation also identified as predictors for creativity (Song et al. 2015). If observed, there is still little research that examines organizational support factor and work system or design. Therefore, this study seeks to fill the creativity determinant gap i.e perceived organizational support and meaning of work.

Perceived organizational support is a concept derived from Social Exchange theory that enables reciprocal processes between organizations treatment and employees. Perceived organizational support is believed to increase employee commitment, enhance performance, and suppress counterproductive behavior as a form of exchange for the organization's efforts to implement fair procedures, resources and management practices support such as favorable workplace conditions, rewards from management, etc (Diliello et al. 2011). Regarding individual creativity, some results show that the perceived support by employees will be able to encourage creative behavior in the context of hospitality industry, involvement of work, and strengthen the potential creativity of employees to be the actual creativity result (Akgunduz et al.2018).
In this study, meaning of work is conceptualized as an effort to find the purpose and meaningful work that is more than just extrinsic motivation (Arnold et al. 2007). With the Job Characteristics Model theory, meaning of work is associated with meaningfulness related to employee's work such as task variety, identity, significance, feedback, and autonomy. Therefore, in general meaning of work is included in the system and job design concept. According to Yeh and Chu (2018), through locus of control and type of individual passion matrix, meaning of work that associated with self-regulation variable is able to encourage individual capacity in knowledge management. One measure of ability in knowledge management is processing and creating knowledge. But the result of this study is still limited to the context of education and e-learning. Not yet generalized to a professional context or creative worker.

Although the effect of perceived organizational support on creativity is considered positive, several studies reveal different findings. Diliello et al. (2011) study found that perceived organizational support did not have a significant interaction effect with creative selfefficacy on individual creativity as dependent variable. The reason is that employee's work environment has several influence sources, from weak ones to strong ones to influence employee behavior and performance. Authors should focus on testing the strongest proximal for predicting individual outcomes. Organizational support has the dimensions of group support, supervisor, and organization itself (Shalley et al. 2000). The result of other studies explain that perceived organizational support has no significant effect on some dimensions of individual creativity (Suifan et al. 2018). Those studies that show inconsistent results between relationship of organizational support and creativity provide opportunities for conceptual gaps related to contingency or situational and personality factors.

As far as the authors effort, there is still little research that explicitly tests relationship between meaning of work and creativity. Study of Akgunduz et al. (2018) examined effect of meaning of work on creativity with its direction was not an independent variable, but mediating with significant positive and partial mediation as the results. Cohen-Meitar et al. (2009) study also examined effect of meaning of work on creativity as a mediator in the model. However, results of this study found that some dimensions of meaning of work did not show a positive correlation with creativity. 
Therefore, stronger research results can be obtained by including moderating variables between the effect of perceived organizational support and meaning of work on employee creativity.

Because the two independent variables represent organizational support and work design, proactive personality variable is chosen as an individual contingency factor that will moderate effect of perceived organizational support and meaning of work on employee creativity. Proactive personality is an individual character that tends to have initiation and to change the work environment and try to explore new ways completing the work (Kim et al. 2009). Proactive individuals also have capacity to use ideas and new ways to improve their performance. Study results show that proactive personality is able to mitigate effects of job dissatisfaction on creative work involvement (Wijaya, 2019). Other results also emphasize proactive personality as an important determinant of the company's innovation capabilities along with determinants of organizational context (Thao and Quynh, 2016). An interesting thing according to the results of Chong and Ma (2010) study found that among individual factors, work environment, and organizational culture, predictors of individual traits had the greatest correlation effect on creative self-efficacy.

This study aims to investigate positive effect of perceived organizational support and meaning of work on employee creativity. Proactive personality is considered as a moderating variable that reinforces positive influence of perceived organizational support and meaning of work on creativity. The implication is, that high level of proactivity is expected to be able to show positive influences which is getting stronger to creativity. Conversely, low level of proactivity will weaken effect of relationship between perceived organizational support, meaning of work, and creativity. This study only focuses on IT industry because the operationalization of variables requires a work design that is closely related to creativity and high autonomy of work. Therefore, authors consider the object of research that best represents this research model is IT industry.

\section{METHODS}

Respondents of this research are employees of information technology companies, especially in Yogyakarta and the some rest are spread in several major cities in Indonesia such as Jakarta, Semarang, Batam, and Banten. Total participation was 155 respondents; 84 from Yogyakarta and 71 from other cities. A total of 155 respondents were obtained in approximately one month.

Because this study is a behavioral research, authors use perceptual/ordinal data type where the perception value is measured on a certain scale. In addition, because it is sourced from primary data, this study uses a questionnaire that has been designed in such a way as to collect data in the field.

Authors collect data through questionnaires distributed both offline and online with Google Form application. Offline data was specifically obtained in Yogyakarta while online questionnaires were from others. Permission for taking data offline is undertaken formally with the approval of the company's HR manager. For online data, authors made shortened-link digital questionnaires distributed to various social media platforms such as Facebook, WhatsApp, LINE, and LinkedIn. The percentage of proportion of respondent obtained offline in Yogyakarta and online outside the region is $54 \%$ and $46 \%$, respectively. All data is used in the analysis because there is no corrupt data.

Authors determine the non-probability sampling using snowball technique for this research. Because this study was limited to employees in IT company and data collection was carried out online, authors collected data by snowballing fashion in which authors chose several respondents who would show another set of respondents with the same characteristics.

Based on the Cochran sample size formula, if the population is unknown or too large, with confidence level of $95 \%$ and maximum error of $10 \%$, the minimum adequacy of sample size is 96 . This study fulfills the adequacy of sample size with 155 respondents. Although population size is unknown, the number of respondents can still be justified for further analysis (Raftery, 1987). 
The distribution of respondents was dominated by following characteristics: male $74.8 \%$, age $<25$ years old $52.9 \%$, single $69 \%$, bachelor degree $61.3 \%$, and tenure $<2$ years $51.6 \%$. Job titles include managers, programmers, developers and data engineers, consultants, analysts, program testers, and IT support. The most job title is programmers 68 respondents or $44 \%$.

This study uses a 5-point Likert-type scale with range 1 $=$ strongly disagree and $5=$ strongly agree. Some items use reversed code to ensure consistency from respondent answers. Employee creativity is measured by four items from (Jaiswal and Dhar, 2015). The item example is, "I demonstrate originality in my work". Perceived organizational support is measured by eight items from (Eisenberger, Huntington, Hutchison, and Sowa, 1986). The item example is, "The organization shows very little concern for me (reversed code)". Meaning of work is measured by six items from (Ashmos and Duchon, 2000). The item example is, "The work I do is connected to what I think is important in my life". Proactive personality is measured by ten items from (Bateman and Crant, 1993). The item example is, "If I see something I don't like, I fix it". Authors consider control variables for creativity because some factors may have an effect on dependent variable that can infere main effect in the model. Control variables are gender, education, organization tenure, and age. Full version of indicators for variables is shown in Table 1.

This model has four variables. Two independent variables, one dependent variable, and one moderating variable (Figure 1). This model focuses on the effects of proactive personality that moderate relationship between perceived organizational support and meaning of work on employee creativity.

Table 1. Full indicators for each variable

\begin{tabular}{|c|c|c|}
\hline Variable name & Code & Description \\
\hline \multirow{4}{*}{$\begin{array}{l}\text { Employee } \\
\text { Creativity }\end{array}$} & $\mathrm{EC} 1$ & I identifies opportunities for new ways of dealing with work \\
\hline & $\mathrm{EC} 2$ & I seeks new ideas and ways to solve problems \\
\hline & EC3 & I generates novel but operable work-related ideas \\
\hline & $\mathrm{EC} 4$ & I demonstrates originality in my work \\
\hline \multirow{8}{*}{$\begin{array}{l}\text { Perceived } \\
\text { Organizational } \\
\text { Support }\end{array}$} & DOP1 & The organisation values my contribution to its well-being \\
\hline & DOP2_r & The organisation fails to appreciate any extra effort from me \\
\hline & DOP3_r & The organisation would ignore any complaint from me \\
\hline & DOP4 & The organisation really cares about my well-being \\
\hline & DOP5_r & Even if I did the best job possible, the organisation would fail to notice \\
\hline & DOP6 & The organisation cares about my general satisfaction at work \\
\hline & DOP7_r & The organisation shows very little concern for me \\
\hline & DOP8 & The organisation takes pride in my accomplishments at work \\
\hline \multirow{10}{*}{$\begin{array}{l}\text { Proactive } \\
\text { Personality }\end{array}$} & PP1 & I am constantly on the lookout for new ways to improve my life \\
\hline & PP2 & Wherever I have been, I have been a powerful force for constructive change \\
\hline & PP3 & Nothing is more exciting than seeing my ideas turn into reality \\
\hline & PP4 & If I see something I don't like, I fix it \\
\hline & PP5 & No matter what the odds, if I believe in something I will make it happen \\
\hline & PP6 & I love being a champion for my ideas, even against others' opposition \\
\hline & PP7 & I excel at identifying opportunities \\
\hline & PP8 & I am always looking for better ways to do things \\
\hline & PP9 & If I believe in an idea, no obstacle will prevent me from making it happen \\
\hline & PP10 & I can spot a good opportunity long before others can see it \\
\hline \multirow[t]{6}{*}{ Meaning of Work } & MOW1 & I see a good relationship between my work and the social aspects of my life (MOW1) \\
\hline & MOW2 & The work I do relates to what I think is important in my life (MOW2) \\
\hline & MOW3 & The work I do in this job is satisfying (MOW3) \\
\hline & MOW4 & The tasks I do in this work are rewarding (MOW4) \\
\hline & MOW5_r & I don't achieve important results from the work I do (MOW5_r) \\
\hline & MOW6 & I am able to achieve important results from the work that I do (MOW6) \\
\hline
\end{tabular}




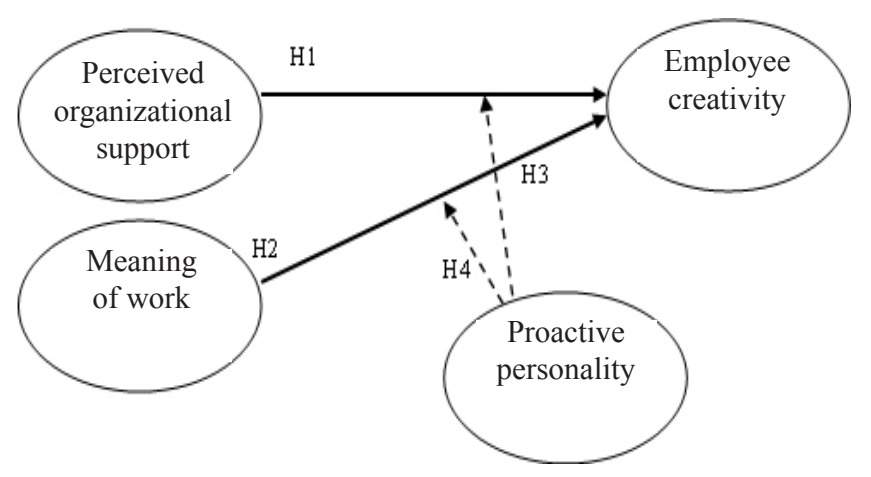

Figure 1. Research framework

\section{Hypotheses Development}

\section{Perceived Organizational Support and Employee Creativity}

In the context of creativity, organizations can provide kinds of support such as recognition and reward toward creative ideas, positive feedback on new ways, and efforts to provide systems that allow knowledge sharing behavior among employees (Chong and Ma, 2010). Yu and Frenkel (2013) study found that organizational support was perceived to be able to improve task performance which in turn led to creative ideas. Organizational support encourages creativity by generating employee's interest in their work (Suifan et al.2018). The mechanism of social exchange allows individuals to work better satisfying organizational expectations as an exchange from supportive management.

H1. Perceived organizational support has a positive and significant effect on employee creativity.

\section{Meaning of Work and Employee Creativity}

Theoy of Job Characteristics Model emphasizes that meaningfulness in working is reflected by several conditions of work that is significance of work for employees, freedom in conducting a job, and competencies include skills and knowledge. If these conditions are met, meaningfulness will encourage employees' intrinsic motivation and stimulate better performance. People who are able to build good meaning in their work will tend to optimize capacity of knowledge to produce creative ideas and suggest new ways (Yeh and Lin, 2015). In other study, meaning of work also has a significant positive effect both on its direct influence on creativity and meaning of work as mediator between relationship of creativity determinants and self-perceived creativity (Akgunduz et al. 2018).

H2. Meaning of work has a positive and significant effect on employee creativity.

\section{Moderating Effect on Employee Creativity}

Study of Joo et al. (2015) in a setting of 291 knowledge workers in South Korean company investigated personal and contextual antecedents on turnover intention. Results show that personal (proactive personality) and contextual antecedents (perceived organizational support) have negative effect on employee turnover intention. Second study of Newman, Schwarz, Cooper, and Sendjaya (2017) shows more firmly moderating effect of proactive personality in the relationship between servant leadership and organizational citizenship behavior. The study was conducted on 446 matched subordinate-supervisors with 30 teams in large Chinese companiy.

H3. Proactive personality moderates the positive and significant influence of perceived organizational support on employee creativity.

Haynie et al. (2017) study revealed that proactive personality and core self-evaluation positively influence task performance through job engagement. This study was conducted in South-Eastern USA with a sample size of 193 teacher respondents. Core self-evaluation has definition that is almost same as the meaning of work. If core self-evaluation focuses on one's perception of the ability to do a job, meaning of work focuses on individual's perception of the significance level of a job. These two variables are also positively correlated with intrinsic motivation which is one of the important predictors for creativity. Another study of Horng et al. (2016) was conducted on 283 permanent employees in tour and hotels companies in Taiwan. Results show that proactive personality strengthen influence of supportive physical work environment and creativity on intrinsic motivation.

H4. Proactive personality moderates the positive and significant influence of meaning of work on employee creativity. 


\section{RESULTS}

\section{Instrument Testing}

Means, standard deviations, correlations, and reliability are shown in Table 2. Based on the results of two-tailed correlations, perceived organizational support, meaning of work, and proactive personality are positively correlated with creativity $(\mathrm{r}=.266, \mathrm{p}<.01 ; \mathrm{r}=.490, \mathrm{p}$ $<.001 ; \mathrm{r}=.437, \mathrm{p}<.001)$. The results indicate initial support for proving hypotheses. Cronbach's alpha value has also exceeded the cutoff for all variables that is .06 for all variables respectively $(.770, .842, .834, .787)$. From this value, indicators and items are considered reliable and have consistency.

Loading factor values are shown in Table 3. Validity test uses Confirmatory Factor Analysis (CFA) method because this study aims to confirm data against the theory. Factor values have been grouped on each construct with a .05 cutoff. Some indicator items need to be dropped to get well defined construct validity. Nevertheless, remaining indicators are still considered capable of representing their latent constructs.

Table 2. Means, standard deviations, correlations, and reliability

\begin{tabular}{|c|c|c|c|c|c|c|c|c|c|c|c|}
\hline & M & S.D. & 1 & 2 & 3 & 4 & 5 & 6 & 7 & 8 & 9 \\
\hline 1. Gender & 1.25 & .43 & & & & & & & & & \\
\hline 2. Age & 1.72 & .89 & -.120 & & & & & & & & \\
\hline 3. Marriage & 1.70 & .47 & .050 & $-.658 * *$ & & & & & & & \\
\hline 4. Education & 2.42 & .90 & -.027 & $.356^{* *}$ & $-.234 * *$ & & & & & & \\
\hline 5. Org. Tenure & 1.67 & .80 & $-.249 * *$ & $.633 * *$ & $-.544 * *$ & $.181^{*}$ & & & & & \\
\hline 6. Employee creativity & 4.14 & .55 & $-.213 * *$ & .066 & -.018 & $.239 * *$ & .041 & $(.770)$ & & & \\
\hline 7. Perceived org. support & 3.73 & .69 & -.012 & -.068 & -.098 & -.101 & -.018 & $.266 * *$ & $(.842)$ & & \\
\hline 8. Meaning of work & 3.97 & .54 & -.126 & .087 & -.156 & $.182^{*}$ & .000 & $.490 * *$ & $.262 * *$ & $(.834)$ & \\
\hline 9. Proactive personality & 3.93 & .56 & -.128 & .044 & .035 & .119 & -.057 & $.437 * *$ & .055 & $.445^{* *}$ & $(.787)$ \\
\hline
\end{tabular}

Table 2. Factor analysis resulta

\begin{tabular}{|c|c|c|c|c|}
\hline \multirow[t]{2}{*}{ Construct and indicatorsb } & \multicolumn{4}{|c|}{ Factor loading } \\
\hline & POS & MOW & $\mathrm{EC}$ & PP \\
\hline \multicolumn{5}{|l|}{ Employee Creativity (EC) } \\
\hline ECitem1 & & & .814 & \\
\hline ECitem2 & & & .782 & \\
\hline ECitem 3 & & & .710 & \\
\hline ECitem4 & & & .543 & \\
\hline \multicolumn{5}{|c|}{ Perceived Organizational Support (POS) } \\
\hline DOPitem1 & .655 & & & \\
\hline DOPitem2_r & .821 & & & \\
\hline DOPitem3_r & .822 & & & \\
\hline DOPitem5_r & .798 & & & \\
\hline DOPitem6 & 630 & & & \\
\hline DOPitem7_r & .661 & & & \\
\hline \multicolumn{5}{|l|}{ Meaning of Work (MOW) } \\
\hline MOWitem1 & & .682 & & \\
\hline MOWitem2 & & .766 & & \\
\hline MOWitem3 & & .799 & & \\
\hline MOWitem4 & & .695 & & \\
\hline MOWitem6 & & .682 & & \\
\hline
\end{tabular}

\begin{tabular}{|c|c|c|c|c|}
\hline \multirow[t]{2}{*}{ Construct and indicatorsb } & \multicolumn{4}{|c|}{ Factor loading } \\
\hline & POS & MOW & $\mathrm{EC}$ & $\mathrm{PP}$ \\
\hline \multicolumn{5}{|l|}{ Proactive Personality (PP) } \\
\hline PPitem1 & & & & .664 \\
\hline PPitem5 & & & & .787 \\
\hline PPitem6 & & & & .724 \\
\hline PPitem8 & & & & .502 \\
\hline PPitem9 & & & & .775 \\
\hline \multicolumn{5}{|c|}{$\begin{array}{l}\text { Total variance explained for four constructs } 59.808 \% \text {. } \\
\text { a Rotated component matrix. }\end{array}$} \\
\hline \multicolumn{5}{|c|}{ Extraction method: Principal component analysis. } \\
\hline \multicolumn{5}{|c|}{$\begin{array}{l}\text { Rotation method: Varimax with kaiser normalization. } \\
\text { b Converged in } 5 \text { iterations. }\end{array}$} \\
\hline
\end{tabular}




\section{Hypotheses Testing}

This study uses hierarchical regression analysis to test hypotheses 1 to 4 including the moderating effect. Multicollinearity effect is also tested in each step. Hierarchical regression uses 4 models; model 1 includes control variables, model 2 includes the main effect, models 3 and 4 enter moderating variable and the interaction effect. Regression results are shown in Table 4.

There were two control variables that remained significant in almost models (gender and education) but only education remained significant in model 4 (B $=.181, \mathrm{p}<.05)$. Perceived organizational support has positive and significant effect on creativity in models 2 , 3 , and 4 with increasing coefficients $(B=1,400, p<.01$, model 4 ), so that hypothesis 1 is supported. Meaning of work has positive and significant effect on creativity in models 2, 3, and 4 but with decreasing coefficients
( $\mathrm{B}=.273, \mathrm{p}<.01$, model 3$)$, so that hypothesis 2 is supported. Then, positive and significant effect of proactive personality on creativity was only in model $3(\mathrm{~B}=.269, \mathrm{p}<.001)$ whereas in model 4 it was not significant. This implied that proactive personality qualifies as moderating variable after interaction effects are entered.

The interaction effect between perceived organizational support and proactive personality is actually negative and significant on creativity $(\mathrm{B}=-1.517, \mathrm{p}<.05$, model 4). This implies that proactive personality weakens relationship between perceived organizational support and creativity. This finding is different from early prediction so hypothesis 3 is not supported. The interaction effect between meaning of work and proactive personality is positive and significant on creativity $(\mathrm{B}=2,350, \mathrm{p}<.01$, model 4$)$, this supports hypothesis 4 .

Table 4. Results of hierarchical regression analysisa

\begin{tabular}{lcccccc}
\hline & \multicolumn{3}{c}{ Employee creativity } & \multicolumn{3}{c}{ Collinearity statsb } \\
\hline & Model 1 & Model 2 & Model 3 & Model 4 & Tolerance & VIF \\
\hline Step 1. Control var & & & & & & \\
Gender & $-.221^{* *}$ & $-.163^{*}$ & $-.137^{*}$ & -.120 & .907 & 1.103 \\
Age & -.020 & -.043 & -.058 & -.053 & .533 & 1.877 \\
Education & $.249^{* *}$ & $.198^{* *}$ & $.189^{* *}$ & $.181^{*}$ & .832 & 1.202 \\
Org. tenure & -.046 & -.005 & .028 & .017 & .555 & 1.802 \\
Step 2. Main effect & & & & & & \\
POS & & $.179^{*}$ & $.194^{* *}$ & $1.400^{* *}$ & .901 & 1.110 \\
MOW & & $.390^{* * *}$ & $.273^{* *}$ & $-1.092^{*}$ & .714 & 1.400 \\
Step 3. Moderating var & & & & & & \\
PP & & & $.269^{* * *}$ & -.256 & .783 & 1.277 \\
Step 4. Interaction effect & & & & & & \\
POS x PP & & & & $-1.517^{*}$ & & \\
MOW x PP & & & & & & \\
Overall F & & & & & & \\
R2 & $.1030^{* * *}$ & & \\
$\Delta \mathrm{F}$ & & .318 & .375 & .424 & & \\
$\Delta \mathrm{R} 2$ & & $.215^{* * *}$ & $.057^{* * *}$ & $.049^{* *}$ & & \\
\hline
\end{tabular}

$\mathrm{N}=155$

$\mathrm{POS}=$ perceived org. support; $\mathrm{MOW}=$ meaning of work; $\mathrm{PP}=$ proactive personality.

a Entries are standardized estimates.

b Entries are from model 3 (excluded interaction effect).

$* \mathrm{p}<0.05,{ }^{* *} \mathrm{p}<0.01,{ }^{* * *} \mathrm{p}<0.001$ 
Multicollinearity test shows that in all models there are no interference of collinearity. This is indicated by the value of tolerance $>.01$ and VIF $<10$. This means that between exogenous variables are mutually independent each other. The $\mathrm{F}$ test showed significant values across all models but there was no significant deviation in model $4(\Delta \mathrm{F}=-.733)$. The value of $\mathrm{R} 2$ also shows increasing coefficient in each model (.103, model 1; .318 , model $2 ; .375$, model $3 ; .424$, model 4 ). This is reinforced by significant addition of coefficient between models. The value of $\Delta R 2$ is one of requirements to indicate whether there is a moderating effect.

Figure 2 and 3 present graph of the interaction effect between proactive personality as a moderating and perceived organizational support and meaning of work as independent variables. From the results obtained interesting finding. In moderating proactive personality, instead of having positive moderating effect, moderating effect of proactive personality actually has significant negative effect on the relationship of perceived organizational support and employee creativity.

This study has three important theoretical contributions to employee creativity literature and perceived organizational support theory. First, Akgunduz et al. (2018) found the same thing that organizational support can improve employee performance and creative ideas more strongly. Yu and Frenkel (2013) found positive relationship of organizational support and creativity in hotel employee settings. This study enriches creativity literature in aspects of research settings because same results are found in different settings that is professional and creative workers. For meaning of work, research results also confirm several studies from Fairlie (2011) and Yeh and Lin (2015). Employees will be encouraged to work better and are not incline to stress when individual is able to see important side of work that arises from the competence and work autonomy they have.

Second, as shown in Figure 3, proactive personality is able to strengthen relationship of meaning of work and creativity. When level of proactivity is low, the effect of meaning of work on creativity is still positive but not quite significant. After proactivity interacts with meaningfulness, level of creativity becomes stronger and more significant. This finding succeed in developing the literature and theory of Job Characteristics Model that the integration between job design and employee meaningfulness gave rise to one's personal compatibility with the work which was able to encourage intrinsic motivation so that creative ideas were more effective. Several studies supporting this finding include Cai et al. (2018), and Horng et al. (2016). The research tried to initiate model of fitness between work, personality, group character, and even physical environment at work.

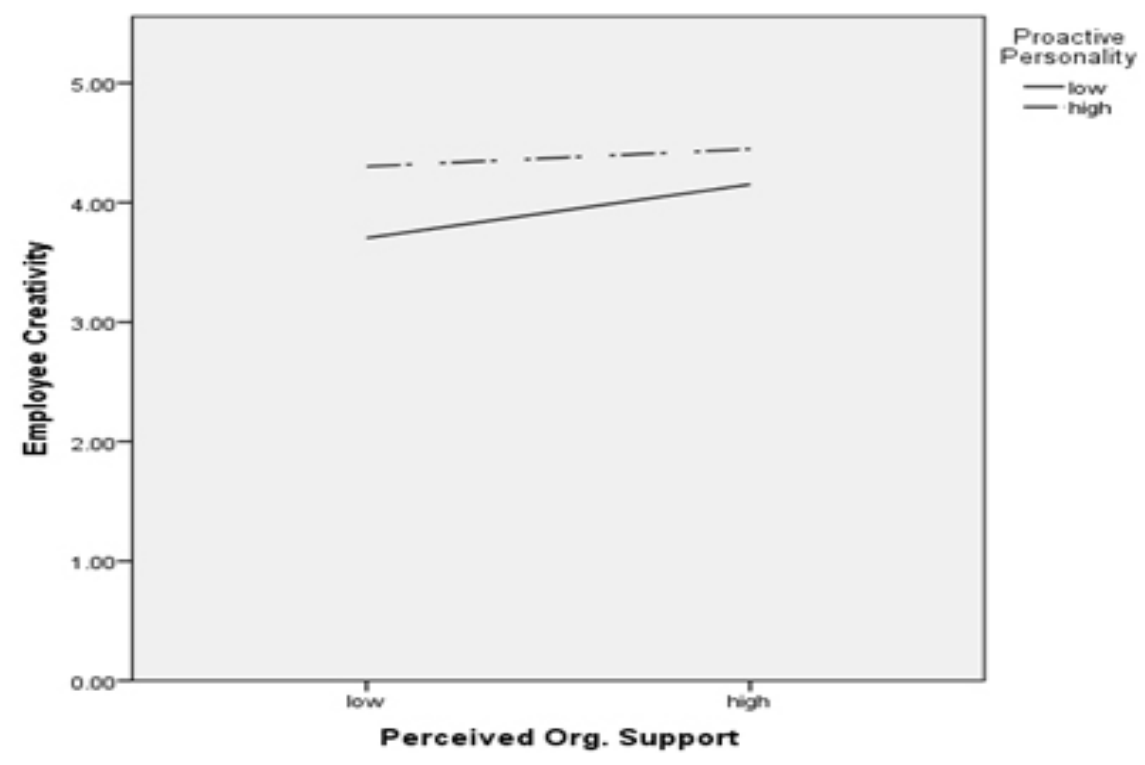

Figure 2. Simple slopes interaction between PP and POS 


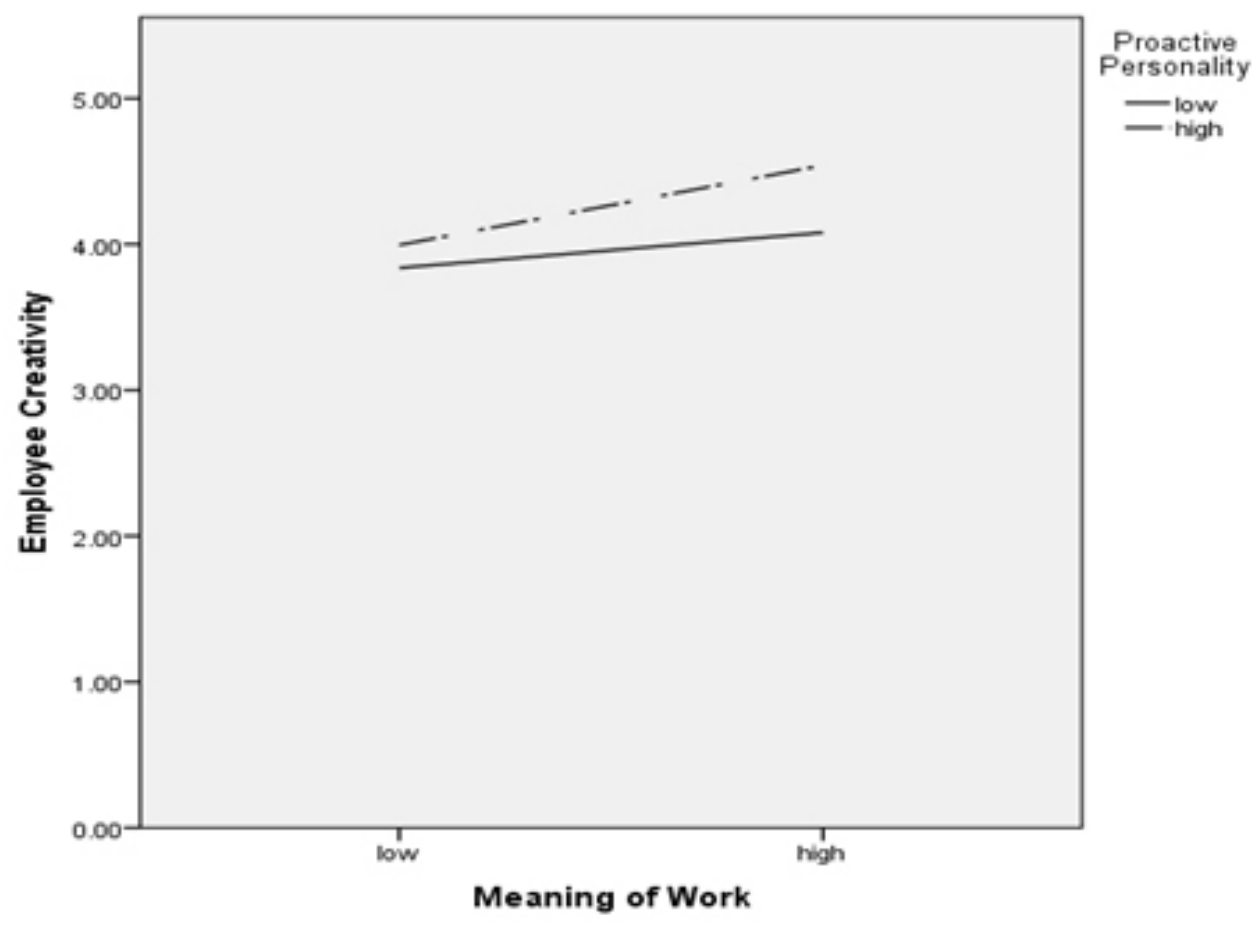

Figure 3. Simple slopes interaction between PP and MOW

Third, as shown in Figure 2, unexpectedly, proactive personality weakens relationship of perceived organizational support and creativity. In other words, when proactivity is high, organizational support felt by employees actually does not significantly influence creativity, although it still has positive effect. Whereas when employee proactivity is low, effect of organizational support on creativity becomes stronger. The argument is Lewin (1997) perspective which considers that the effects of employee's work environment are influenced by several sources. Among these sources are strong and weak ones. The strength of influence source depends on the proximal focus. In this study perceived organizational support is considered as a weak proximal. Organizational support is considered unfocused, too general, so that such of support are not felt directly by employees. For example, Shalley et al. (2000) reported that job-related characteristics have stronger proximal source than organizational characteristics to enforce creative performance. In addition, employees with high proactivity perceive that they have great control over the work. This causes general organizational support to be less important because it is perceived as a formality of the job (Diliello et al.2011; Suifan et al.2018).

\section{Managerial Implications}

These findings provide understanding to managers, especially in information technology companies, to increase level of organizational support and meaningfulness of employees towards their work. When people feel support and importance of work, employees will also show positive outcomes such as emergence of intrinsic motivation, responsibility and better job autonomy so as to encourage problem solving in new, unique, and more effective ways. Managers can design such work that provides high meaningfulness. For example, granting job autonomy, feedback and response to the output of a job, and job design that meets aspects of identity, significance, and task variety. In addition, given that organizational support is one of weak proximal weak resource, managers should not make forms of support that are too general and not focus on employee expectations. Instead, managers can provide support with stronger proximal such as support from supervisors, coworkers, or team members. This requires companies to provide greater delegation to the lower structures.

Because the interaction of proactive personality with support and meaningfulness allows employees to work more active and creative, at the initial of recruitment, managers must ensure that company has a selection system that is able to identify level of employee 
proactivity. Proactive personality becomes important asset for someone to be more proactively involved in organizational problems, proposed ideas and solutions, and more courageous to initiate changes that benefit the company. Organizations will more easily respond to external demands when they have proactive employees.

\section{CONCLUSIONS AND RECOMMENDATIONS}

\section{Conclusions}

This study has fulfilled research objectives that were set at beginning of the study. This study has been able to prove statistically that perceived organizational support and meaning of work can increase employee creativity. Therefore, this study contributes to understanding of organizational support theory and literature review in the field of creativity. In addition, from the contingency approach, moderating effect of proactive personality is proven to be able to strengthen relationship between meaning of work and employee creativity.

Interesting finding was also obtained from this study. The authors initially suspected that moderating effect of proactive personality had significant positive effect on relationship of perceived organizational support and creativity. However, the results show that moderating effect of proactive personality actually has significant negative effect on relationship of perceived organizational support and creativity. This emphasizes that in the field of organizational support studies, a foci perspective where organizational support is directed at a specific subject (i.e supervisor, co-worker, members of team etc) is starting to become requirement for similar and future research agenda.

\section{Recommendations}

Although purpose of this study has been reached, research still has limitations that must get concern. First, sample of professional and knowledge workers is certainly not enough with 155 sample sizes. Future research could replicate this model but with more sample size for the purpose of generalizing results. Second, this research measures construct of creativity as self-rated by employees. This certainly raises challenge to the common rater bias issue. Future research might be able to measure creativity more objectively, for example, supervisor raters or produced creative output. Finally, to enrich creativity literature, future research can focus more on identifying stronger proximal resources of support like supervisory support, coworkers, family, or team members.

\section{REFERENCES}

Akgunduz Y, Alkan C, Gök ÖA. 2018. Perceived organizational support, employee creativity and proactive personality: The mediating effect of meaning of work. Journal of Hospitality and Tourism Management 34:105-114. https://doi. org/10.1016/j.jhtm.2018.01.004

Arnold KA, Turner N, Barling J, Kelloway EK, Mckee MC. 2007. Transformational leadership and psychological well-being: The mediating role of meaningful work. Journal of Occupational Health Psychology 12(3):193-203. https://doi. org/10.1037/1076-8998.12.3.193

Ashmos DP, Duchon D. 2000. Spirituality at work: A conceptualization and measure. Journal of Management Inquiry 9(2):134-145. https://doi. org $/ 10.1177 / 105649260092008$

Barczak G, Lassk F, Mulki J. 2010. Antecedents of team creativity: An examination of team emotional intelligence, team trust and collaborative culture. Creativity and Innovation Management 19(4):332-345. https://doi.org/10.1111/j.14678691.2010.00574.x

Bateman TS, Crant JM. 1993. The proactive component of organizational behavior: A measure and correlates. Journal of Organizational Behavior 14(2):103-118. https://doi.org/10.1002/ job.4030140202

Cai D, Cai Y, Sun Y, Ma J. 2018. Linking empowering leadership and employee work engagement: The effects of person-job fit, person-group fit, and proactive personality. Frontiers in Psychology 9:1-12. https://doi.org/10.3389/ fpsyg.2018.01304

Chong E, Ma X. 2010. The influence of individual factors, supervision and work environment on creative self-efficacy. Creativity and Innovation Management 19(3):233-247. https://doi. org/10.1111/j.1467-8691.2010.00557.x

Cohen-Meitar R, Carmeli A, Waldman DA. 2009. Linking meaningfulness in the workplace to employee creativity: The intervening role of organizational identification and positive psychological experiences. Creativity 
Research Journal 21(4):361-375. https://doi. org/10.1080/10400410902969910

Diliello TC, Houghton JD, Dawley D. 2011. Narrowing the creativity gap: The moderating effects of perceived support for creativity. The Journal of Psychology 145(3):151-172. https://doi.org/10. 1080/00223980.2010.548412

Eisenberger R, Huntington R, Hutchison S, Sowa D. 1986. Perceived organizational support. Journal of Applied Psychology 71(3):500-507. https:// doi.org/10.1037/0021-9010.71.3.500

FairlieP.2011.Meaningfulwork, employeeengagement, and other key employee outcomes: Implications for human resource development. Advances in Developing Human Resources 13(4):508-525. https://doi.org/10.1177/1523422311431679

Girard LF. 2010. Sustainability, creativity, resilience: Toward new development strategies of port areas through evaluation processes. International Journal of Sustainable Development 13(1-2):161-184. https://doi.org/10.1504/ IJSD.2010.035106

Haynie JJ, Flynn CB, Mauldin S. 2017. Proactive personality, core self-evaluations, and engagement: The role of negative emotions. Management Decision 55(2): 450-463. https:// doi.org/10.1108/MD-07-2016-0464

Horng JS, Tsai CY, Yang TC, Liu CH, Hu DC. 2016. Exploring the relationship between proactive personality, work environment and employee creativity among tourism and hospitality employees. International Journal of Hospitality Management 54:25-34. https://doi. org/10.1016/j.ijhm.2016.01.004

Jaiswal NK, Dhar RL. 2015. Transformational leadership, innovation climate, creative selfefficacy and employee creativity: A multilevel study. International Journal of Hospitality Management 51:30-41. https://doi. org/10.1016/j.ijhm.2015.07.002

Joo BKB, Hahn HJ, Peterson SL. 2015. Turnover intention: The effects of core self-evaluations, proactive personality, perceived organizational support, developmental feedback, and job complexity. Human Resource Development International 18(2):116-130. https://doi.org/10. 1080/13678868.2015.1026549

Khalili A. 2016. Linking transformational leadership, creativity, innovation, and innovation-supportive climate. Management Decision 54(9):22772293. https://doi.org/10.1108/MD-03-2016-
0196

Kim TY, Alice AE, Hon HY, Crant AJM. 2009. Proactive personality, employee creativity, and newcomer outcomes: A longitudinal study. Journal of Business and Psychology 24(1):93-103. https:// doi.org/10.1007/s10869-009-9094-4

Lewin GW. 1997. Behavior and Development as a Function of the Total Situation. Washington DC: American Psychological Association. https:// doi.org/10.1037/10269-024

Mittal S, Dhar RL. 2015. Transformational leadership and employee creativity: Mediating role of creative self-efficacy and moderating role of knowledge sharing. Management Decision 53(5): 94-910. https://doi.org/10.1108/MD-072014-0464

Newman A, Schwarz G, Cooper B, Sendjaya S. 2017. How servant leadership influences organizational citizenship behavior: The Roles of $\operatorname{lmx}$, empowerment, and proactive personality. Journal of Business Ethics 145(1):49-62. https:// doi.org/10.1007/s10551-015-2827-6

Raftery AE. 1987. Inference and prediction for a general order statistic model with unknown population size. Journal of the American Statistical Association 82: 1163-1168. https://doi.org/10.1 080/01621459.1987.10478554

Shalley CE, Gilson LL, Blum TC. 2000. Matching creativityrequirements and theworkenvironment: effects on satisfaction and intentions to leave. Academy of Management Journal 43(2):215223. https://doi.org/10.5465/1556378

Song W, Yu H, Zhang Y, Jiang W. 2015. Goal orientation and employee creativity: The mediating role of creative role identity. Journal of Management \& Organization 21(1):82-97. https://doi. org/10.1017/jmo.2014.64

Suifan TS, Abdallah AB, Al Janini M. 2018. The impact of transformational leadership on employees' creativity: The mediating role of perceived organizational support. Management Research Review 41(1):113-132. https://doi.org/10.1108/ MRR-02-2017-0032

Thao Tai H, Quynh Mai N. 2016. Proactive personality, organizational context, employee creativity and innovative capability. International Journal of Organizational Analysis 24(3):370-389. https:// doi.org/10.1108/IJOA-04-2015-0857

Wijaya NHS. 2019. Linking job dissatisfaction, learning motivation, creative work involvement, and proactive personality. Problems and 
Perspectives in Management 17(1):32-41. https://doi.org/10.21511/ppm.17(1).2019.04

Yeh YC, Chu LH. 2018. The mediating role of selfregulation on harmonious passion, obsessive passion, and knowledge management in e-learning. Educational Technology, Research and Development 66(3):615-637. https://doi. org/10.1007/s11423-017-9562-x

Yeh YC, Lin CF. 2015. Aptitude-treatment interactions during creativity training in e-learning: how meaning-making, self-regulation, and knowledge management influence creativity. Journal of Educational Technology \& Society 18(1):119131.

Yu C, Frenkel SJ. 2013. Explaining task performance and creativity from perceived organizational support theory: Which mechanisms are more important? Journal of Organizational Behavior 34(8):1165-1181. https://doi.org/10.1002/ job. 1844 